\title{
Forensic odontostomatology
}

\author{
Geoffrey H. Sperber \\ School of Dentistry, Faculty of Medicine \& Dentistry, University of Alberta, Edmonton, Canada \\ gsperber@ualberta.ca
}

Received 2 September 2013; revised 7 October 2013; accepted 17 October 2013

Copyright (C 2013 Geoffrey H. Sperber. This is an open access article distributed under the Creative Commons Attribution License, which permits unrestricted use, distribution, and reproduction in any medium, provided the original work is properly cited.

\begin{abstract}
Teeth are the most durable and enduring structures of human anatomy, surviving fragmentation, partial incineration and severe decomposition. The role of teeth in identification is manifested as significant specifiers of deceased or living individuals. The characteristics of dental morphology are genetically-inherited and ascribable to racial or familial ancestry. Dental age identification is attributable to young individuals. The chemical composition of teeth identifies diets during life, as attritional wear patterns do. Bite marks transiently relate to the perpetrator of attacks. Dental restorations and prostheses are evidence of economic, cultural and social status of deceased individuals. Palatal rugae patterns are unique to individuals. The DNA identification of postmortem dental pulp tissue relating to a deceased individual or a living relative is the ultimate criterion of positive association of forensic recognition, as other means of identification become less effective, forensic dental identification increases in importance.
\end{abstract}

Keywords: Forensics; Teeth; Identity; DNA

\section{INTRODUCTION}

Teeth, by virtue of their durability, are the most significant organs of forensic identification for several reasons [1]. Teeth are the quintessential last organs to disintegrate by postmortem decay or incineration long after the remainder of body parts has disappeared. The morphology of teeth is genetically inherited, providing clues of familial and racial evidence of identification [2]. The attritional wear patterns of dentitions indicate the nature of dietary intake, possibly pointing to cultural influences during the lifetime of the deceased. The presence of dental restorations of gold, amalgam, composite resins or prostheses provides insight into the deceased's ethnicity, economic, geographic and cultural status. The occurrence of characteristic wear patterns on teeth reveal tooth cleaning habits, pipe clenching, vice-like gripping employment or oral musical instrument usage.

Factors of dental caries, missing or extra teeth, alignment of the dental arches and prosthetic appliances [3] can indicate identification of unknown remains. Antemortem clinical dental history is an indispensable aid to identity. Dental radiographs provide clinching evidence of previous patients' records matching recovered remains. Smoking prevalence and frequent ingestion of acidic drinks are permanently imprinted on teeth, revealing recognition of the deceased's habits. Periodontal status is revealed by the degree of alveolar bone resorption.

\section{ODONTOLOGY}

Odontogenesis imposes life-long signatures upon developing teeth, as a kymographic record of metabolic events occurring during the development of teeth. Hence, malnutrition, diseases or drug administration during the different periods of odontogenesis are permanently recorded in the histopathology of enamel and dentine. Genetic mutations of amelogenesis and dentinogenesis are distinctive markers and are of forensic significance [4].

Spectroscopic analyses of the elements contained in enamel and dentine are amenable to interpretation of the ambient contemporaneous milieu at the time of their formation. Hence, differing $\mathrm{C}^{12}$ and $\mathrm{C}^{13}$ ratios and Oxygen isotope variations incorporated into enamel apatite composition reveal dietary intake during enamel formation $[5,6]$.

Enamel, dentine and pulp experience physiological and pathological changes during a lifetime. Enamel becomes more mineralized and thinner and smoothens out initial perikymatal imbrications. Dentine becomes thicker, thereby decreasing dental pulp volume. The pulp tissue becomes more fibrous and less vascular. These aging changes can be detected by measuring varying degrees of tooth fluorescence that correlates with different stages of 
aging, indicating the age range of the deceased [7].

\section{BITE MARKS}

Bite mark analysis is dependent upon the material into which the teeth have imprinted. The harder the imprinted material leads to a greater clarity of bite marks matching with a particular dentition. Food material varies greatly in density and hardness and retention of dental impresssions. Chewed hard cheese or hard candy can retain bite marks for a considerable time. Bite marks on human flesh have a very limited duration of recognition before distortion sets in, requiring immediate identification, comparison and matching with the dentition of the alleged perpetrator [8]. However, the deposition of saliva into the tooth indentations might allow recovery of salivary cells to permit DNA identification of the retained genetic material that may match that of the potential perpetrator [9].

\section{PALATAL RUGOSCOPY}

The peculiarity of individual palatal rugae patterns is established during fetal development and retained throughout life [10]. The identification of an individual based on a unique palatal rugae pattern has been compared with fingerprint identification [11-13] in determining the ethnicity and sex of an individual. This methodology is of particular significance in edentulous persons, where all odontological evidence has been lost [14].

\section{DNA IDENTIFICATION}

The capability of retrieving DNA information from the pulp material of teeth makes this means of near absolute identification the ultimate diagnostic criterion. Because dental pulps are ensconced within the most durable tissues, i.e. enamel and dentine, their uncontaminated preservation makes this tissue the most likely to reveal pristine DNA evidence for the longest period after death [15]. However, DNA may also be derived from soft tissue or blood adhering to teeth.

The methods used for DNA profiling are complex and expensive. The postmortem DNA extracted from the dental pulps of unidentified individuals can be compared with DNA isolated from known antemortem samples such as clothing, tooth brushes, hair brushes or buccal smear samples. The advent of the polymerase chain reaction (PCR) technique allows unlimited DNA amplification for analysis.

Short tandem repeats (STR) analyses that identify hypervariable regions of DNA that present consecutive repetitions of fragments that have two to seven base pairs (bp) provide the basis for this analytical technique [16]. A central database of DNA profiles from all user laboratories is the core of the national DNA database in the
United States, and is accessible as the Combined DNA Index System (CODIS) [17].

\section{CONCLUSION}

The many varied technologies of identification are applicable to the main tissue components of teeth, enamel, dentine and pulp, each with their unique biomechanical and biochemical characteristics makes forensic odontological recognition the sine qua non method of detection of unknown human material. Teeth tell tales long after death prevails, revealing much of the history of the deceased. Forensic odontologists become an indispensable component of multiple disaster and mass grave investigations requiring identification of human remains [18].

\section{REFERENCES}

[1] Hinchcliffe, J. (2011) Forensic odontology: Dental identification. British Dental Journal, 210, 219-224.

[2] Scott, G.R. and Turner II, C.G. (1997) The anthropology of modern human teeth. Cambridge University Press, Cambridge.

[3] Kamble, V.B., Desai, R.G., Arabbi, K.C., et al. (2013) Denture marking: A valuable aid inforensic identification. Indian Journal of Forensic Medicine \& Toxicology, 2, 187-192.

[4] Nanci, A. (2013) Ten Cate’s oral histology: development, structure and function. 8th Edition, Elsevier, St. Louis.

[5] Blyth, L. (2001) Oxygen isotope analysis and tooth enamel phosphate and its application to archeology. Totem. The University of Western Ontario Journal of Anthropology, 1, Article 2.

[6] Zavala-Alonso, V., Loyola-Rodriguez, J.P., Terrones, H., et al. (2012) Analysis of molecular structure of human enamel with fluorosis using micro-Raman spectroscopy. Journal of Oral Science, 54, 93-98. http://jos.dent.nihon-u.ac.jp/journal/54/1/93.pdf

[7] Da Silva, R.D., da Siva, M.A.D., de Oliveira, O.B., et al. (2013) Dental fluorescence: Potential forensic use. Forensic Science International, 231, 167-171. http://dx.doi.org/10.1016/j.forsciint.2013.05.001

[8] Pretty, I.A. and Sweet, D. (2000) Anatomical location of bite marks and associated findings in 101 cases from the United States. Journal of Forensic Science, 45, 812-814.

[9] Sweet, D. et al. (1997) PCR-based DNA typing of saliva stains recovered from human skins. Journal of Forensic Science, 42, 447-451.

[10] English, W.R., Robison, S.F., Summit, J.B., et al. (1988) Individuality of human palatal rugae. Journal of Forensic Science, 33, 718-726.

[11] Caldas, I.M., Magalhaes, T. and Afonsa, A. (2007) Establishing identity using cheiloscopy and palatoscopy. Forensic Science International, 165, 1-9. http://dx.doi.org/10.1016/j.forsciint.2006.04.010 
[12] Thomas, C.J. and Kotze, T.J. (1983) The palatal rugaepattern: A new classification. Journal of the Dental Association of South Africa, 38, 153-157.

[13] Hauser, G., Daponte, A. and Roberts, M.J. (1989) Palatal rugae. Journal of Anatomy, 165, 237-249. http://www.ncbi.nlm.nih.gov/pmc/articles/PMC1256673/

[14] Rai, B. and Amand, S.C. (2007) Palatal rugae: In forensic examination. Indian International Journal of Forensic Medicine and Toxicology, 5, 23-25.

[15] Sweet, D. and Hildebrand, D. (1998) Recovery of DNA from human teeth by cryogenic grinding. Journal of Forensic Science, 43, 1199-1202.
[16] da Silva, R.H.A., Sales-Peres, A., de Oliveira, R.N., et al. (2007) Use of DNA technology in forensic dentistry. Journal of Applied Oral Science, 15, 156-161. http://dx.doi.org/10.1590/S1678-77572007000300002

[17] Combined DNA Index System (CODIS) (2011) Federal bureau of investigations. http://www.justice.gov/oig/reports /FBI/00126/final.pdf

[18] London, A.J., Parker, L.S. and Aronson, J.D. (2013) DNA identification after conflict or disaster. Science, 341, 11781179. http://dx.doi.org/10.1126/science.1238085 